\title{
Hydrogenated Silicon Carbide Thin Films Prepared with High Deposition Rate by Hot Wire Chemical Vapor Deposition Method
}

\author{
M. M. Kamble, ${ }^{1}$ V. S. Waman, ${ }^{1,2}$ A. H. Mayabadi, ${ }^{1}$ S. S. Ghosh, ${ }^{1}$ B. B. Gabhale, ${ }^{1}$ \\ S. R. Rondiya, ${ }^{1}$ A. V. Rokade, ${ }^{1}$ S. S. Khadtare, ${ }^{1}$ V. G. Sathe, ${ }^{3}$ T. Shripathi, ${ }^{3}$ H. M. Pathan, ${ }^{4}$ \\ S. W. Gosavi, ${ }^{4}$ and S. R. Jadkar ${ }^{4}$ \\ ${ }^{1}$ School of Energy Studies, University of Pune, Pune 411 007, India \\ ${ }^{2}$ Department of Physics, Modern College, Pune 411 005, India \\ ${ }^{3}$ UGC-DAE-CSR, University Campus, Khandawa Road, Indore 452 017, India \\ ${ }^{4}$ Department of Physics, University of Pune, Pune 411 007, India
}

Correspondence should be addressed to S. R. Jadkar; sandesh@physics.unipune.ac.in

Received 28 April 2013; Revised 23 September 2013; Accepted 15 October 2013; Published 4 February 2014

Academic Editor: Mariana Braic

Copyright (C) 2014 M. M. Kamble et al. This is an open access article distributed under the Creative Commons Attribution License, which permits unrestricted use, distribution, and reproduction in any medium, provided the original work is properly cited.

\begin{abstract}
Structural, optical, and electrical properties of hydrogenated silicon carbide $(\mathrm{SiC}: \mathrm{H})$ films, deposited from silane $\left(\mathrm{SiH}_{4}\right)$ and methane $\left(\mathrm{CH}_{4}\right)$ gas mixture by HW-CVD method, were investigated. Film properties are carefully and systematically studied as function of deposition pressure which is varied between 200 mTorr and 500 mTorr. The deposition rate is found to be reasonably high $\left(9.4 \mathrm{~nm} / \mathrm{s}<r_{d}<15.54 \mathrm{~nm} / \mathrm{s}\right)$. Formation of SiC:H films is confirmed by FTIR, Raman, and XPS analysis. XRD and Raman analysis revealed that with increasing deposition pressure amorphization occurs in SiC:H films. FTIR spectroscopy analysis shows that bond density of $\mathrm{C}-\mathrm{H}$ decreases while $\mathrm{Si}-\mathrm{C}$ and $\mathrm{Si}-\mathrm{H}$ bond densities increase with increasing deposition pressure. Total hydrogen content increases with increasing deposition pressure and was found to be $<20$ at.\%. The absence of band $\sim 1300-$ $1600 \mathrm{~cm}^{-1}$ in the Raman spectra implies negligible $\mathrm{C}-\mathrm{C}$ bond concentration and formation of nearly stoichiometric SiC:H films. The band gap shows increasing trend with increasing deposition pressure. The high value of Urbach energy suggests increased structural disorder in SiC:H films. Finally, it has been concluded that $\mathrm{CH}_{4}$ can be used as effective carbon source in $\mathrm{HW}-\mathrm{CVD}$ method to prepare stoichiometric SiC:H films.
\end{abstract}

\section{Introduction}

Hydrogenated silicon carbide $(\mathrm{SiC}: \mathrm{H})$ is a versatile material due to its interesting mechanical, electrical, and optical properties. The material has been extensively studied due to potential applications in variety of fields such as mechanical protection coating [1], an optical coating for solar cells [2], in light emitting diodes and solar cells [3], and in X-ray lithography masks [4]. The physical properties of $\mathrm{SiC}: \mathrm{H}$ are strongly dependent on composition of $\mathrm{Si}$ and $\mathrm{C}$ in the films and hence dependent on $\mathrm{Si}$ and $\mathrm{C}$ source gases and the preparation technique employed.

A variety of preparation methods and different gases have been used to synthesize $\mathrm{SiC}: \mathrm{H}$ thin films to obtain desired physical and electronic properties at low substrate temperature. These include plasma enhanced chemical vapor deposition (PE-CVD) [5], electron cyclotron resonance CVD [6], magnetron sputtering [7], pulsed laser deposition (PLD) [8], ion implantation [9], and molecular beam epitaxy (MBE) [10]. For the source of Si precursors, usually preferred gases are silane $\left(\mathrm{SiH}_{4}\right)$, disilane $\left(\mathrm{Si}_{2} \mathrm{H}_{6}\right)$, and tetrachlorosilane $\left(\mathrm{SiCl}_{4}\right)$, and for the source of $\mathrm{C}$ precursors methane $\left(\mathrm{CH}_{4}\right)$, acetylene $\left(\mathrm{C}_{2} \mathrm{H}_{2}\right)$, propane $\left(\mathrm{C}_{3} \mathrm{H}_{8}\right)$, methylbenzene/toluene $\left(\mathrm{C}_{7} \mathrm{H}_{8}\right)$, hexane $\left(\mathrm{C}_{6} \mathrm{H}_{14}\right)$, methyl chloride $\left(\mathrm{CH}_{3} \mathrm{Cl}\right)$, carbon tetrachloride $\left(\mathrm{CCl}_{4}\right)$, and other gases have been used for making these films [11]. Various organometallic precursors such as tetramethylsilane $\left[\left(\mathrm{CH}_{3}\right) 4 \mathrm{Si}\right.$, TMS] [12], methyltrichlorosilane $\left[\mathrm{CH}_{3} \mathrm{SiCl}_{3}, \mathrm{MTS}\right]$ [13], and hexamethyldisilane $\left[\left(\mathrm{CH}_{3}\right) 6 \mathrm{Si}_{2}, \mathrm{MDS}\right]$ [14] have been also used as single-source system to reduce the growth temperature of $\mathrm{SiC}: \mathrm{H}$ films. 
TABLE 1: Deposition parameters employed for the preparation of intrinsic SiC:H films by HW-CVD.

\begin{tabular}{lc}
\hline Deposition parameter & Value \\
\hline Deposition pressure $\left(P_{d}\right)$ & $200-500 \mathrm{mTorr}$ \\
Filament temperature $\left(T_{\mathrm{fil}}\right)$ & $2000^{\circ} \mathrm{C}$ \\
Substrate temperature $\left(T_{\text {sub }}\right)$ & $250^{\circ} \mathrm{C}$ \\
Silane $\left(\mathrm{SiH}_{4}\right)$ flow rate $\left(F_{\mathrm{SiH}_{4}}\right)$ & $3.5 \mathrm{sccm}$ \\
Methane $\left(\mathrm{CH}_{4}\right)$ flow rate $\left(F_{\mathrm{CH}_{4}}\right)$ & $25 \mathrm{sccm}$ \\
Filament to substrate distance $\left(d_{s-f}\right)$ & $4 \mathrm{~cm}$ \\
Deposition time $(t)$ & $25 \mathrm{~min}$ \\
\hline
\end{tabular}

Among these, PE-CVD method with $\mathrm{SiH}_{4}$ and $\mathrm{CH}_{4}$ gas mixtures has been the most widely studied configuration to obtain $\mathrm{SiC}: \mathrm{H}$ films. However, this method is subject to some drawbacks such as low carbon incorporation efficiency and a low deposition rate [15].

Hot wire chemical vapor deposition (HW-CVD) method has received considerable attention in recent years owing to its capability to synthesize $\mathrm{SiC}: \mathrm{H}$ films at low substrate temperature $[16,17]$ at higher deposition rates. Recently, the method has been successfully employed for the synthesis of $\mathrm{SiC}: \mathrm{H}$ window layers in thin film $\mathrm{Si}$ solar cells achieving maximum conversion efficiency of 9.6\% [18]. The two major advantages of employing HW-CVD method for the synthesis of $\mathrm{Si}$ based alloy coatings are the absence of the deleterious electrons and ions and surface charges which avoid powder formation and second is high dissociation rate of source gases which leads to higher deposition rate. Various carbon source gases like methane $\left(\mathrm{CH}_{4}\right)[19]$, monomethylsilane $\left(\mathrm{SiH}_{3} \mathrm{CH}_{3}\right.$, MMS) [20], acetylene $\left(\mathrm{C}_{2} \mathrm{H}_{2}\right)$ [21], and so forth have been used in HW-CVD for synthesis of SiC:H thin films. These gases have shown strong influence on physical properties and morphology of the SiC:H films. So far, the HW-CVD method has not been studied extensively for the synthesis of $\mathrm{SiC}: \mathrm{H}$ films using methane $\left(\mathrm{CH}_{4}\right)$ as carbon source gas and only few reports exist in the literature [22, 23]. It is with this motivation that we initiated the detailed study of synthesis and characterization of $\mathrm{SiC}: \mathrm{H}$ films by HW-CVD method. In this paper, we report influence of deposition pressure on structural, optical, and electrical properties.

\section{Experimental}

2.1. Film Preparation. Intrinsic hydrogenated silicon carbide ( $\mathrm{SiC}: \mathrm{H})$ thin films were deposited simultaneously on corning \# 7059 glass and c-Si wafers (111) in a HW-CVD system, details of which have been described elsewhere [24]. Films were prepared by using a mixture of $\mathrm{SiH}_{4}$ and $\mathrm{CH}_{4}$ gases (MSG). The flow rate of all the gases was kept constant while deposition pressure was varied from 200 mTorr to 500 mTorr. The substrate temperature was held constant during the deposition at desired value accurately using a thermocouple and temperature controller. Other deposition parameters are listed in Table 1.

2.2. Film Characterization. Dark conductivity $\left(\sigma_{\text {dark }}\right)$, charge carrier activation energy $\left(E_{\text {act }}\right)$, and photo conductivity

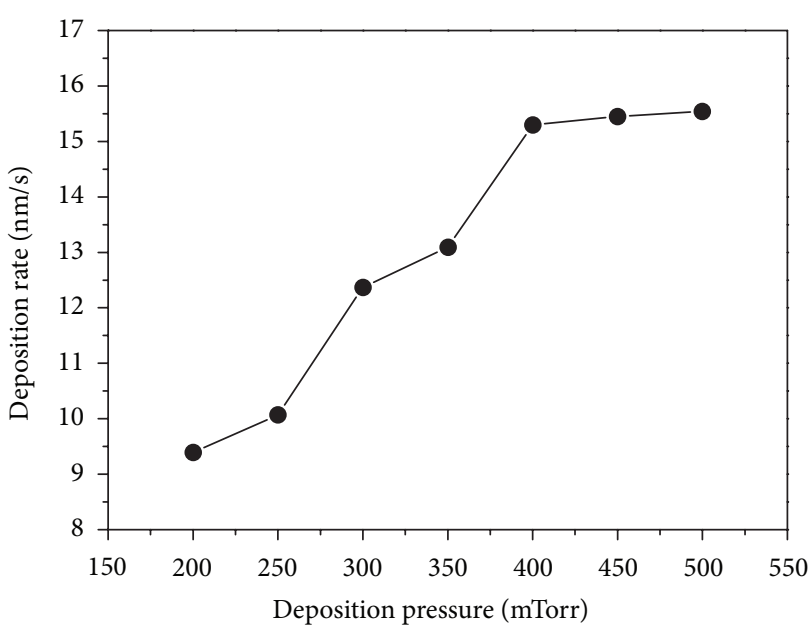

FIGURE 1: Variation of deposition rate as a function of deposition pressure for $\mathrm{SiC}: \mathrm{H}$ films deposited by HW-CVD method.

$\left(\sigma_{\text {photo }}\right)$ were measured using samples of dimension $3 \mathrm{~cm} \times$ $1 \mathrm{~cm}$ deposited on glass substrate with coplanar $\mathrm{Al}$ electrodes $0.5 \mathrm{~mm}$ apart deposited by vacuum evaporation. The FTIR spectra were recorded in transmission mode by using FTIR spectrophotometer (JASCO, 6100-type A) in the range $400-4000 \mathrm{~cm}^{-1}$. The band gap of the $\mathrm{SiC}: \mathrm{H}$ films was deduced from transmittance and reflectance spectra of the films deposited on corning glass and was measured using a JASCO, V-670 UV-Visible spectrophotometer in the range 250-1100 nm. Raman spectra were recorded with a Jobin Yvon Horibra LABRAM-HR apparatus in the range 200$1200 \mathrm{~cm}^{-1}$. The spectrometer has backscattering geometry for detection of Raman spectrum with the resolution of $1 \mathrm{~cm}^{-1}$. The excitation source was $632.8 \mathrm{~nm}$ line of $\mathrm{He}-\mathrm{Ne}$ laser. The power of the Raman laser was kept less than $5 \mathrm{~mW}$ to avoid laser induced crystallization on the films. The Xray photo-electron spectra (XPS) were recorded using a VSW ESCA instrument with a total energy resolution $\sim 0.9 \mathrm{eV}$ fitted with an $\mathrm{Al} \mathrm{K} \alpha$ source (soft X-ray source at $1486.6 \mathrm{eV}$ ) at base vacuum $>10^{-9}$ Torr. The XPS signal was obtained after several scans in the acquisition process. The spectra were recorded for the specific elements ( $\mathrm{Si}, \mathrm{C}$, O, etc.). Low angle $\mathrm{X}$ ray diffraction pattern was obtained by X-ray diffractometer (Bruker D8 Advance, Germany) using $\mathrm{Cu} \mathrm{K}_{\alpha}$ line $(\lambda=$ $1.54 \AA$ ) at a grazing angle of $1^{\circ}$. Thickness of films was determined by profilometer (KLA Tencor, $\mathrm{P}-16=+$ ) and was further confirmed by UV-Visible spectroscopy using the method proposed by Swanepoel [25].

\section{Results and Discussion}

3.1. Variation in Deposition Rate. Films were deposited for a desired time period and the deposition rate is calculated from thickness measurement. Variation of deposition rate $\left(r_{d}\right)$ as a function of deposition pressure $\left(P_{d}\right)$ is shown in Figure 1. As seen from the figure, the deposition rate increases from $9.4 \mathrm{~nm} / \mathrm{s}$ to $15.54 \mathrm{~nm} / \mathrm{s}$ when deposition pressure increases from 200 mTorr to 500 mTorr. 


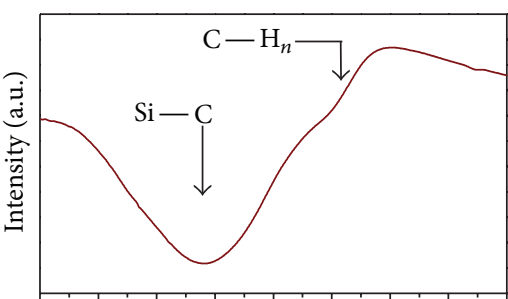

$500 \quad 6007008009001000110012001300$

Wavenumber $\left(\mathrm{cm}^{-1}\right)$

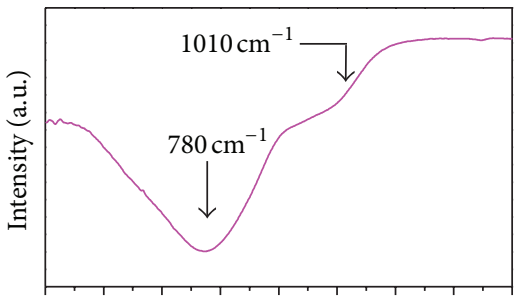

$\begin{array}{llllll}500 & 600 & 700 & 800 & 9001000110012001300\end{array}$

Wavenumber $\left(\mathrm{cm}^{-1}\right)$

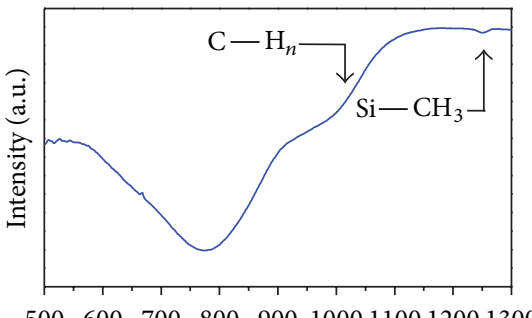

Wavenumber $\left(\mathrm{cm}^{-1}\right)$

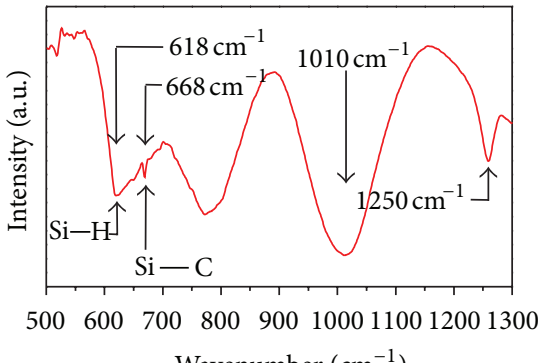

Wavenumber $\left(\mathrm{cm}^{-1}\right)$

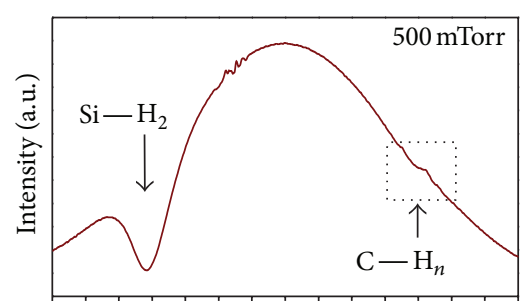

18002000220024002600280030003200 Wavenumber $\left(\mathrm{cm}^{-1}\right)$

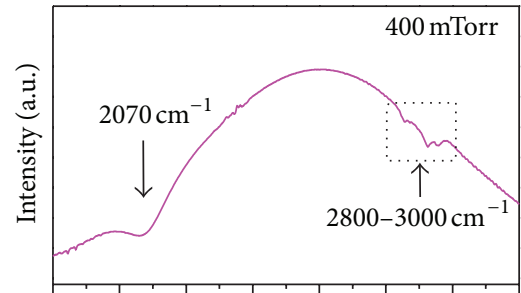

18002000220024002600280030003200

Wavenumber $\left(\mathrm{cm}^{-1}\right)$

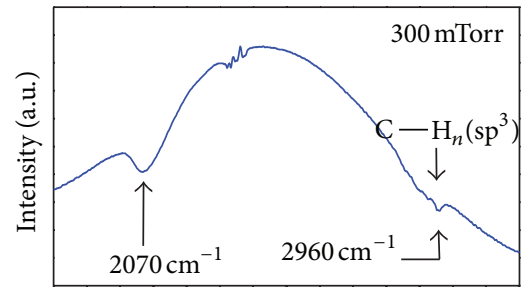

$180020002200 \quad 24002600280030003200$ Wavenumber $\left(\mathrm{cm}^{-1}\right)$

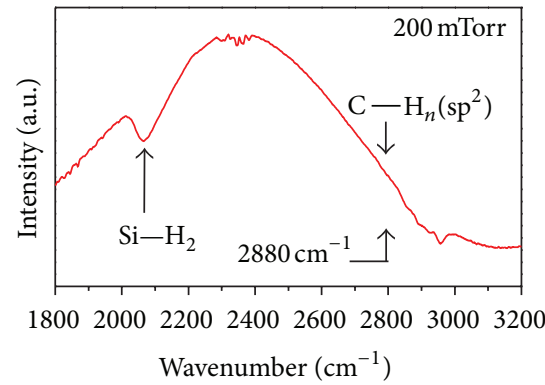

FIGURE 2: FTIR spectra of some SiC:H films normalized to thickness deposited by HW-CVD method.

In the present study, the temperature of hot wire, silane, and methane gas flow rates are kept constant at $2000^{\circ} \mathrm{C}$, $3.5 \mathrm{sccm}$, and $25 \mathrm{sccm}$, respectively, and the deposition pressure was varied from 200 mTorr to 500 mTorr using automated throttle valve. Thus, impingement of source gases and hence film formation precursors depends on deposition pressure and is given by [26]

$$
\text { Impingement rate }=\frac{P_{d}}{\sqrt{2 \pi m k_{B} T}},
$$

where $P_{d}$ is the deposition pressure, $m$ is the molecular mass, $k_{B}$ is Boltzman's constant, and $T$ is the gas temperature. Therefore, with increase in deposition pressure, the dissociation of gas molecules on hot wire increases. This increases the number of film-forming radicals. Consequently, the deposition rate increases with increase in deposition pressure. It is worth highlighting that the deposition rate obtained in the present study for SiC:H films using HW-CVD is much higher than the PE-CVD [27], low frequency inductively coupled plasma (ICP) CVD [28], and very recently DC saddle PE-CVD [29] grown $\mathrm{SiC}: \mathrm{H}$ films.

\subsection{Fourier Transform Infrared (FTIR) Spectroscopy Analysis.} The bonding configurations of the deposited thin films were investigated by the Fourier transform infrared (FTIR) spectroscopy. Figure 2 shows the thickness normalized FTIR transmission spectra of some $\mathrm{SiC}: \mathrm{H}$ films deposited by HWCVD method at different deposition pressures $\left(P_{d}\right)$. For clarity, the spectra have been broken horizontally into two parts, namely, between $500-1300 \mathrm{~cm}^{-1}$ and $1800-3200 \mathrm{~cm}^{-1}$. 
As seen from the FTIR spectra, the films deposited at $P_{d}=200$ mTorr show the various peaks centered at $\sim 618 \mathrm{~cm}^{-1}, \sim 668 \mathrm{~cm}^{-1}, \sim 780 \mathrm{~cm}^{-1}, \sim 1010 \mathrm{~cm}^{-1}, 1250 \mathrm{~cm}^{-1}$, and $2070 \mathrm{~cm}^{-1}$ corresponding to $\mathrm{Si}-\mathrm{H}$ wagging or rocking [30], Si-C stretching [31], Si-C (stretching)/Si- $\mathrm{CH}_{3}$ (wagging) [27, 32, 33], $\mathrm{C}-\mathrm{H}_{n}$ wagging [33, 34], $\mathrm{Si}-\mathrm{CH}_{3}$ bending [31], and $\mathrm{Si}-\mathrm{H}_{n}$ stretching $(n=1,2)$ [35] modes, respectively. The absorption band $\sim 2800-3000 \mathrm{~cm}^{-1}$ is attributed to stretching vibration of $\mathrm{C}-\mathrm{H}_{n}$ groups in $\mathrm{sp}^{2}$ $\left(2880 \mathrm{~cm}^{-1}\right)$ and $\mathrm{sp}^{3}\left(2960 \mathrm{~cm}^{-1}\right)$ configurations [36]. With increase in deposition pressure, absorption peaks $\sim 618 \mathrm{~cm}^{-1}$ and $\sim 668 \mathrm{~cm}^{-1}$ are merged into $780 \mathrm{~cm}^{-1}$ absorption peak and its intensity increases with increase in deposition pressure. This result suggests increase in $\mathrm{Si}-\mathrm{C}$ bond density and hence carbon content in the film with increase in deposition pressure. At the same time, intensity of $\mathrm{C}-\mathrm{H}_{n}$ band located at $\sim 1010 \mathrm{~cm}^{-1}$ drastically gets reduced and becomes weak which indicates decrease in $\mathrm{C}-\mathrm{H}$ bond density with increase in deposition pressure. Furthermore, increasing the deposition pressure, $\mathrm{C}-\mathrm{H}_{n}$ absorption band located in the range $\sim 2800-3000 \mathrm{~cm}^{-1}$ also becomes weak implying decrease in $\mathrm{C}-\mathrm{H}$ bond density. The existence of vibrational modes at $1010 \mathrm{~cm}^{-1}$ and in the range $2800-3000 \mathrm{~cm}^{-1}$ in the FTIR spectra over the entire range of deposition pressure studied suggests that the $\mathrm{C}-\mathrm{H}_{n}$ group has a substantial fraction in SiC:H alloys.

To determine the $\mathrm{H}$ content we have followed the method given by Brodsky et al. [37]. The absorption coefficient $(\alpha)$ can be obtained through the Beer-Lambert law:

$$
T=T_{o} e^{-\alpha(\omega) d},
$$

where $d$ is the film thickness, $T$ and $T_{o}$ are the transmittance of the film substrate and the substrate, respectively, and $\alpha(\omega)$ is the absorption coefficient at frequency $(\omega)$. The number of $\mathrm{Si}-\mathrm{C}\left(\mathrm{N}_{\mathrm{Si}-\mathrm{C}}\right), \mathrm{Si}-\mathrm{H}\left(\mathrm{N}_{\mathrm{Si}-\mathrm{H}}\right)$, and $\mathrm{C}-\mathrm{H}\left(\mathrm{N}_{\mathrm{C}-\mathrm{H}}\right)$ bonds has been estimated by taking area under the curve for the respective peak using the relation [38-40]

$$
N=A_{\omega} \int \frac{\alpha(\omega)}{\omega} d \omega=A_{\omega} I_{\omega}
$$

where the oscillator strength, $A_{\omega}$, has a value of $2.13 \times$ $10^{19} \mathrm{~cm}^{-2}$ [39], $1.4 \times 10^{20} \mathrm{~cm}^{-2}$ [40], and $1.35 \times 10^{21} \mathrm{~cm}^{-2}$ [39] for $\mathrm{Si}-\mathrm{C}, \mathrm{Si}-\mathrm{H}$, and $\mathrm{C}-\mathrm{H}$, respectively. The merged $\mathrm{Si}-\mathrm{H}$, $\mathrm{C}-\mathrm{H}$, and $\mathrm{Si}-\mathrm{C}$ bands are deconvoluted to separate out the different bonding configurations present in the films. Typical deconvoluted FTIR spectra for the film deposited at $P_{d}=$ 350 mTorr are shown in Figure 3.

Variation of $\mathrm{Si}-\mathrm{C}, \mathrm{Si}-\mathrm{H}$, and $\mathrm{C}-\mathrm{H}$ bond densities and total hydrogen content as a function of deposition pressure are displayed in Figure 4. As seen from the figure, the bond density of $\mathrm{C}-\mathrm{H}$ (Figure 4(c)) decreases while $\mathrm{Si}-\mathrm{C}$ and $\mathrm{Si}-$ $\mathrm{H}$ bond densities (Figures 4(a) and 4(b)) increase with increase in deposition pressure. These results suggest that at higher deposition pressure unbonded $\mathrm{C}$ atoms are attached to $\mathrm{Si}$ and at lower deposition pressure it is attached to the hydrogen. The total hydrogen content increases with increase in deposition pressure and was found $<20$ at.\% (Figure $4(d)$ ).

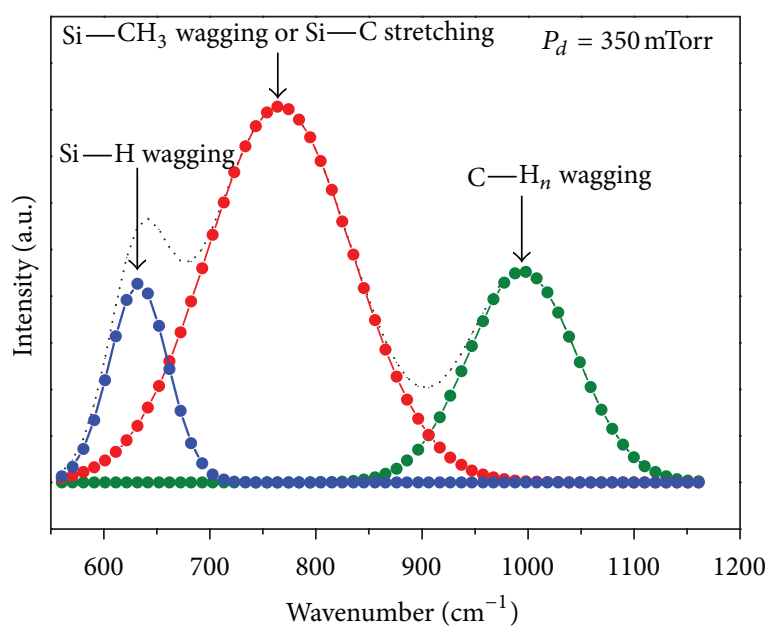

FIgURE 3: Typical deconvoluted FTIR spectra for the film deposited at $P_{d}=350$ mTorr by using HW-CVD method.

The increase in total hydrogen content can attribute to increase in $\mathrm{Si}-\mathrm{H}$ bond density due to the amorphization of the films at high deposition pressure as revealed by low angle $\mathrm{XRD}$ and Raman measurements (discussed later).

3.3. Low Angle X-Ray Diffraction (XRD) Analysis. Low angle $\mathrm{XRD}$ measurements were carried out to investigate the thin film's crystal structure. Films deposited on corning glass were used for the XRD measurements. Figure 5 displays the XRD pattern of the films deposited at various deposition pressures $\left(P_{d}\right)$.

As seen from the XRD patterns, the films deposited at $P_{d}=200$ mTorr show dominant peaks located around $2 \theta \sim$ $28.4^{\circ}, \sim 47.3^{\circ}$, and $\sim 56.1^{\circ}$ corresponding to the (111), (220), and (311) crystallographic planes of c-Si, respectively, indicating that these films contain nanocrystalline-Si phase. Thus, the estimated crystallite sizes $\left(d_{\mathrm{X}-\text { ray }}\right)$ of (111) orientation of the films deposited at deposition pressures 200 mTorr and 300 mTorr are 6.3 and $5.8 \mathrm{~nm}$, respectively. The film deposited at $P_{d}=300$ mTorr, the diffraction peaks corresponding to all the crystallographic planes were found to decrease, both in intensity and sharpness. Then again films deposited at higher deposition pressures ( $P_{d}=400$ mTorr and 500 mTorr), all crystallographic planes disappears in the XRD pattern indicating that films are amorphous. Moreover, a broad shoulder centered at $\sim 38.4^{\circ}$ and $\sim 42.2^{\circ}$ is also observed in the XRD pattern for the films deposited at deposition pressures 400 mTorr and 500 mTorr, respectively. These broad shoulders are associated with 3C-SiC structure [41]. A broad hump at $2 \theta \sim 38.4^{\circ}$ in the pattern indicates $\mathrm{SiC}$ nanocrystals of average crystallite size $\sim 3 \mathrm{~nm}$ ingrained in the amorphous silicon carbide alloy. Therefore, it is concluded that, with increase in deposition pressure, the incorporated $\mathrm{C}$ atoms induce amorphization in the Si network due to local deformation caused by the carbon ad-atoms. These results are also consistent with Raman results. The increase in hydrogen content with increase in deposition pressure due to amorphization further supports this. 


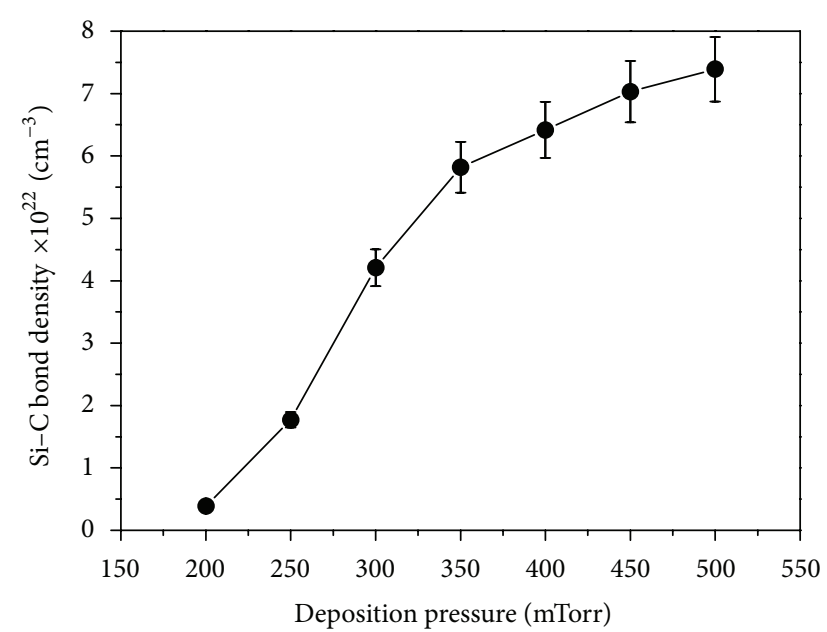

(a)

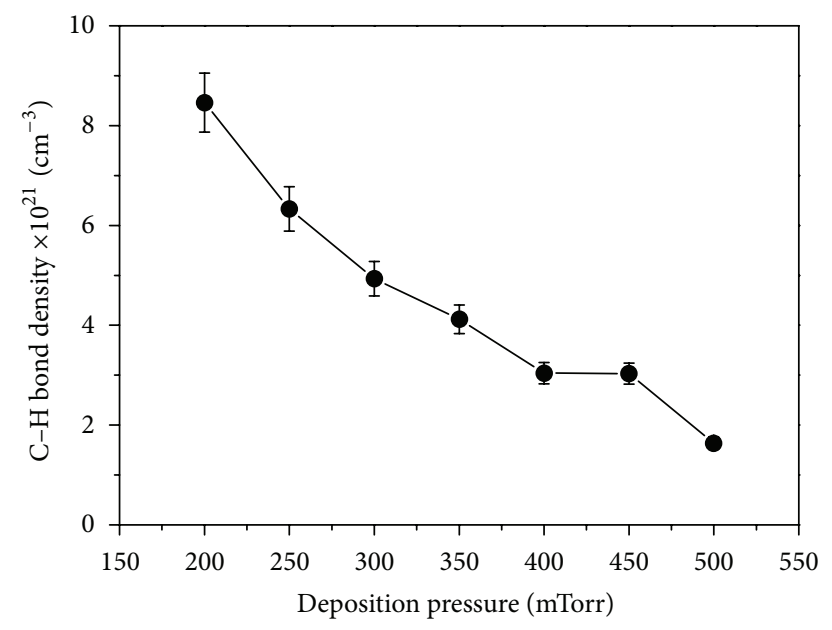

(c)

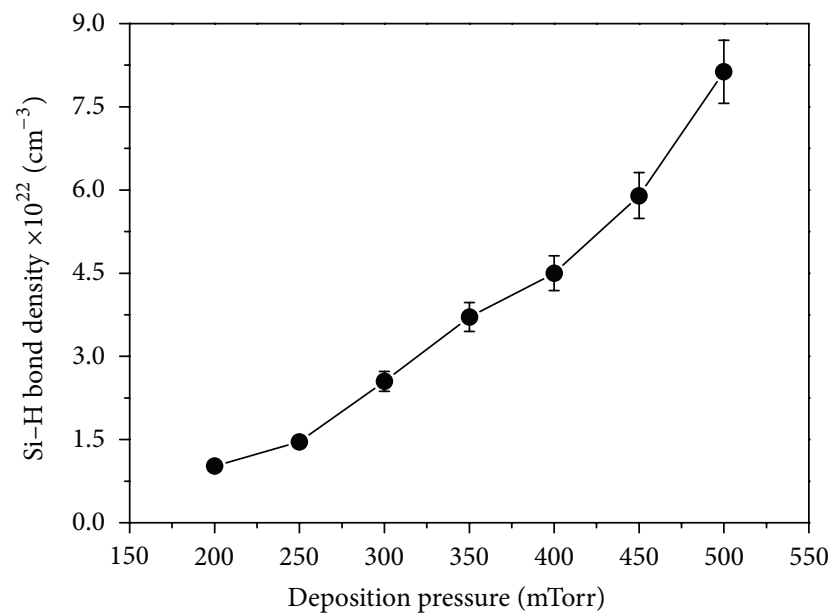

(b)

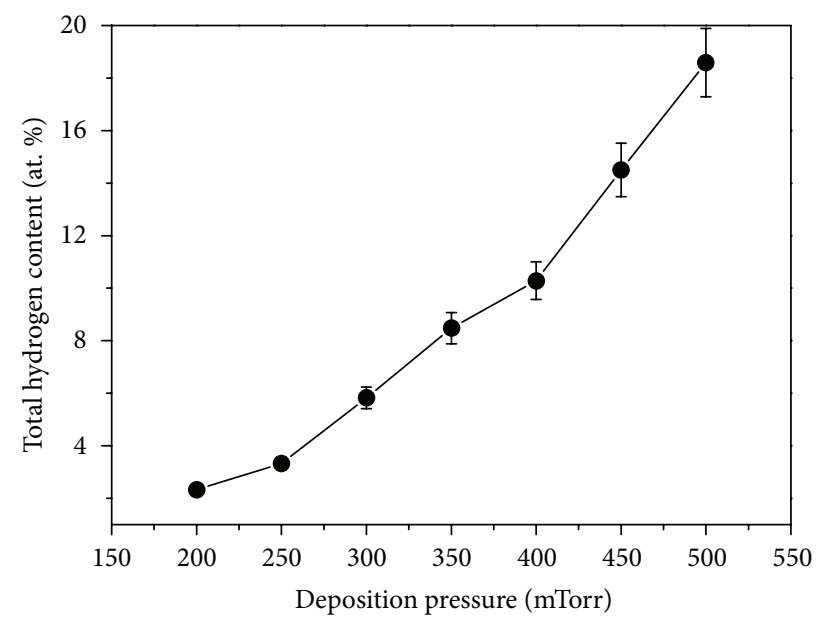

(d)

Figure 4: Variation of (a) Si-C bond density, (b) $\mathrm{Si}-\mathrm{H}$ bond density, (c) $\mathrm{C}-\mathrm{H}$ bond density, and (d) total hydrogen content $\left(\mathrm{C}_{\mathrm{H}}\right)$ as a function of deposition pressure for SiC:H films deposited by HW-CVD method.

3.4. Raman Spectroscopy Analysis. Raman spectroscopy is a powerful technique for the characterization of $\mathrm{SiC}: \mathrm{H}$ structures in particular, since it allows the identification of various polytypes. In addition, Raman spectral parameters such as peak position, intensity, and line-width provide useful information on the crystal quality. Figure 6 shows the Raman spectra in the range $200-1200 \mathrm{~cm}^{-1}$ of SiC:H films deposited at various deposition pressures by HW-CVD method using $\mathrm{CH}_{4}$ as carbon source gas. The $\mathrm{Si}-\mathrm{C}$ band, which is expected to be observed in the range $600-1000 \mathrm{~cm}^{-1}$, is very weak as the Raman efficiency of the $\mathrm{Si}-\mathrm{C}$ band is much smaller than that of $\mathrm{C}-\mathrm{C}$ and $\mathrm{Si}-\mathrm{Si}$ bands [42]. However, following observations have been made from the Raman spectra for the films deposited at different deposition pressures.

(1) The spectra clearly show that a small band centered at $\sim 300 \mathrm{~cm}^{-1}$ corresponds to $\mathrm{Si}-\mathrm{Si}$ longitudinal optic (LO) mode and its intensity increases with increase in deposition pressure.
(2) For the film deposited at $P_{d}=200$ mTorr, the Raman spectrum exhibits a sharp peak centered at $\sim 519 \mathrm{~cm}^{-1}$ (Transverse Optic, TO) originated from the contribution of small Si nanocrystals [43]. With increase in deposition pressure the TO peak shift toward lower wavenumber and its sharpness decline. In fact, the TO peak shifts from $517 \mathrm{~cm}^{-1}$ to $484 \mathrm{~cm}^{-1}$ and its line width; that is, full width at half maximum (FWHM, $\Gamma_{\mathrm{TO}}$ ) increases from $48 \mathrm{~cm}^{-1}$ to $98 \mathrm{~cm}^{-1}$ when deposition pressure increased from 200 mTorr to 500 mTorr. The shifting of TO peak towards lower wave number and increase in its line width indicate amorphization in Si network due to local deformation caused by the carbon atoms. These results are consistent with low angle XRD analysis.

(3) For the film deposited at $P_{d}=500$ mTorr, the Raman spectra show a broad peak centered at $\sim 485 \mathrm{~cm}^{-1}$. This may be assigned to either $\mathrm{SiC}$ acoustic phonons particularly reported for smaller SiC crystallites [44] 


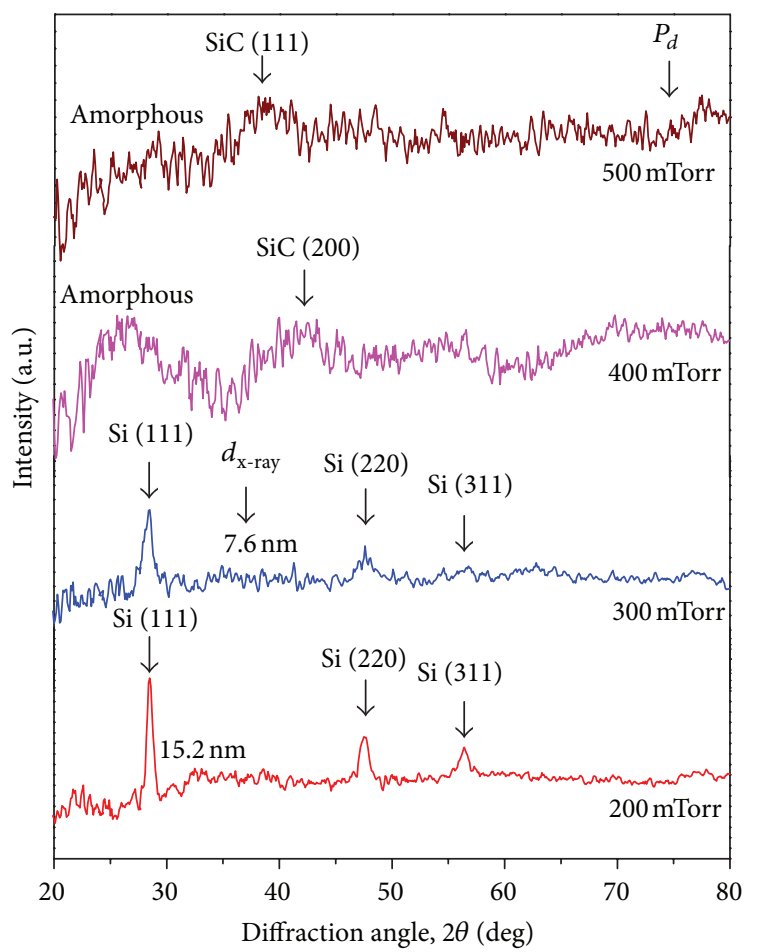

FIgUre 5: Low angle X-ray diffraction pattern of some SiC:H films deposited at different deposition pressures.

or to TO phonon mode of a-Si:H [45]. As there was no c-Si phase in the $\mathrm{SiC}: \mathrm{H}$ film observed for the films deposited at higher deposition pressures $\left(P_{d}>\right.$ 300 mTorr), broad peak centered at $\sim 485 \mathrm{~cm}^{-1}$ in the Raman spectra may be assigned to a-Si:H. Furthermore, the Raman spectra show a weak signal at $\sim 865 \mathrm{~cm}^{-1}$, which can be attributed to $\mathrm{Si}-\mathrm{C}$ bonds [46].

(4) In addition to these, Raman spectra show a broad shoulder centered at $\sim 672 \mathrm{~cm}^{-1}$ for the film deposited at $P_{d}=400 \mathrm{mTorr}$. Chen et al. [20] have also observed the similar broad shoulder for HW-CVD deposited $\mathrm{SiC}: \mathrm{H}$ films. However, the origin of this broad shoulder is still not clear.

(5) For all deposition pressures, the Raman spectra show a broad shoulder centered at $\sim 972 \mathrm{~cm}^{-1}$ and can be assigned to $\mathrm{SiCl}$ longitudinal optic (LO) phonon vibrations [20]. Their intensity shows slight increasing trend with increase in deposition pressure suggesting increase in $\mathrm{Si}-\mathrm{C}$ bond concentration in $\mathrm{SiC}: \mathrm{H}$ films. This is consistent with FTIR spectroscopy analysis (see Figure 3).

(6) Another interesting feature observed in Raman spectra of our $\mathrm{SiC}: \mathrm{H}$ films is the complete absence of Raman band in the region $1300-1600 \mathrm{~cm}^{-1}$ (not shown) associated with $\mathrm{C}-\mathrm{C}$ bonds [47] indicating negligible $\mathrm{C}-\mathrm{C}$ bond concentration over the entire range of deposition pressure studied. This result is an indicative of formation of nearly stoichiometric $\mathrm{SiC}: \mathrm{H}$ thin films by $\mathrm{HW}-\mathrm{CVD}$ using $\mathrm{CH}_{4}$ carbon source gas.

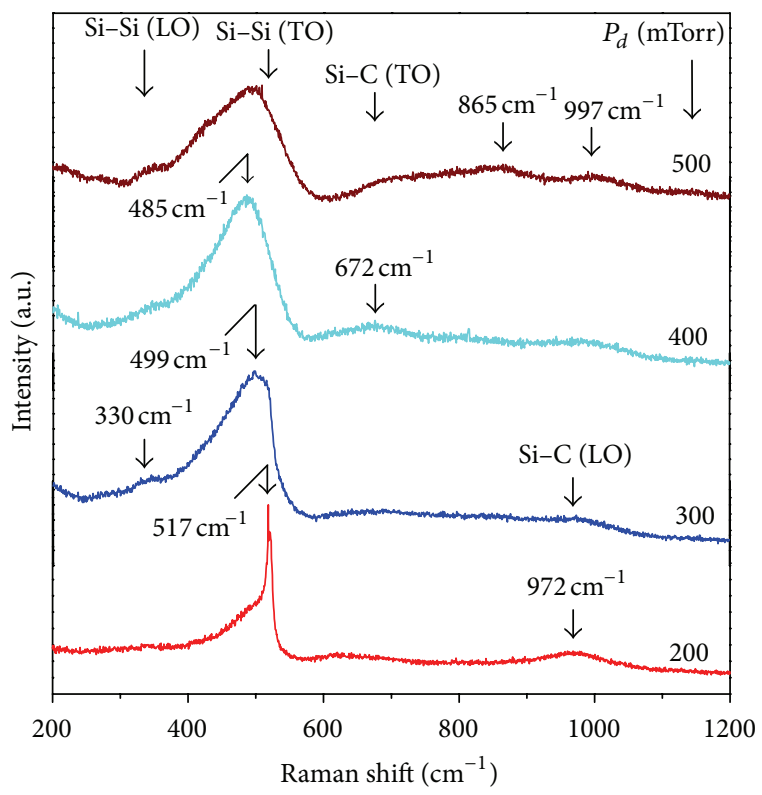

FIGURE 6: Raman spectra of SiC:H films deposited by HW-CVD at various deposition pressures.

3.5. X-Ray Photoelectron Spectroscopy (XPS) Analysis. The formation of SiC:H films using $\mathrm{CH}_{4}$ as carbon source gas in HW-CVD was further confirmed from the X-ray photoelectron spectroscopy (XPS) measurements. Figure 7(a) shows the XPS wide scan of HW-CVD deposited SiC:H film prepared at $P_{d}=350$ mTorr.

The scan shows the silicon (Si 2p and Si 2s), carbon (C 1s), and oxygen (O 1s) peaks. The oxygen peak originates due to adsorbed oxygen and surface oxidation of the film. The oxygen was found to be incorporated in $\mathrm{SiC}: \mathrm{H}$ films prepared at even lower base pressure than the pressure employed for the XPS measurements [21]. Figures $7(b)-7(d)$ show typical narrow scan deconvoluted XPS spectra of the Si (2p), $\mathrm{C}$ (1s), and oxygen $\mathrm{O}$ (1s) electron state, respectively. The spectrum has been decomposed into several peaks based on the assumption that each peak consists of the Gaussian/ Lorentzian sum function. The Si $(2 \mathrm{p})$ peak $(96 \mathrm{eV}-106 \mathrm{eV})$ was deconvoluted into the $\mathrm{Si}-\mathrm{Si}, \mathrm{Si}-\mathrm{C}$, and $\mathrm{Si}-\mathrm{O}$ peaks [48]. The C (1s) peak $(280 \mathrm{eV}-292 \mathrm{eV})$ was deconvoluted into the $\mathrm{C}-\mathrm{Si}, \mathrm{C}-\mathrm{C}, \mathrm{C}-\mathrm{OH}$, and $\mathrm{C}=\mathrm{O}$ peaks [49]. The $\mathrm{O}(1 \mathrm{~s})$ peak $(530 \mathrm{eV}-537 \mathrm{eV})$ was deconvoluted into $\mathrm{O}-\mathrm{Si}$, $\mathrm{O}-\mathrm{CH}$, $\mathrm{O}=\mathrm{C}$, and $\mathrm{O}-\mathrm{O}$ peaks. All films show essentially the same peak components, but with different relative intensities and compositions. The energy positions [48-57] of these peaks are listed in Table 2. The Si (2p) peak could be fitted with three peaks due to $\mathrm{Si}-\mathrm{C}$ at $100.5 \mathrm{eV}, \mathrm{Si}-\mathrm{Si} / \mathrm{Si}: \mathrm{H}$ at $99.2 \mathrm{eV}$, and $\mathrm{Si}-\mathrm{O}_{x}$ at $103.2 \mathrm{eV}$, respectively. The peak at $283.2 \mathrm{eV}$ is due to the carbon atoms in $\mathrm{C}-\mathrm{Si}$ bonds and the peak at $284.6 \mathrm{eV}$ and $286.4 \mathrm{eV}$ corresponds to carbon atoms having graphitic and diamond bonding. As $\mathrm{Si}-\mathrm{Si} / \mathrm{Si}: \mathrm{H}$ and $\mathrm{C}-\mathrm{C} / \mathrm{C}-$ $\mathrm{H}$ peak energy positions are very close to each other, more detailed deconvolutions are not able at the present stage of the precision in the measurement of XPS spectra. The atomic concentration for the film deposited at $P_{d}=350 \mathrm{mTorr}$ 


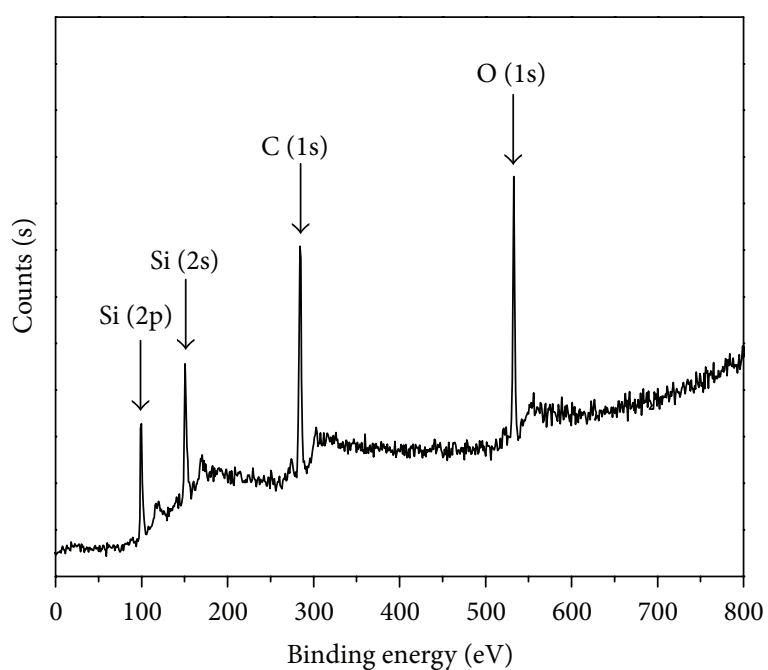

(a) Wide scan

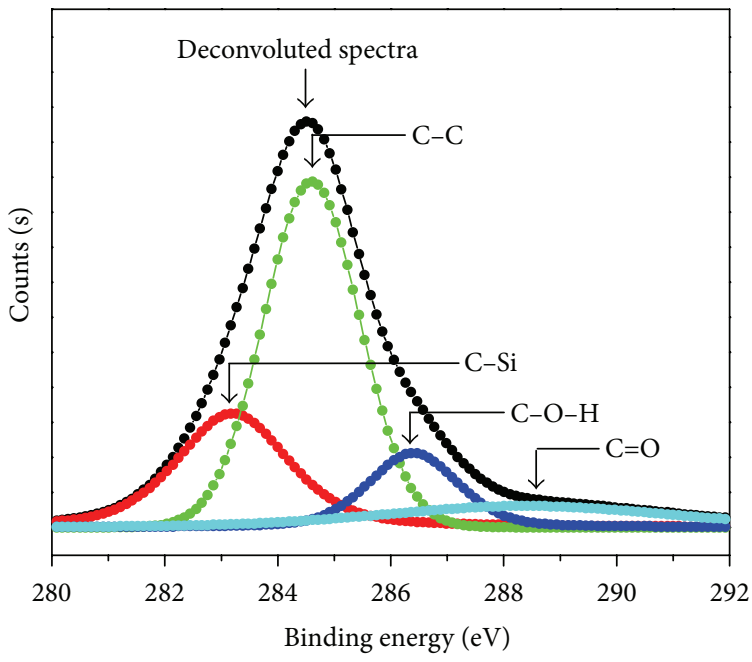

(c) $\mathrm{Cls}$

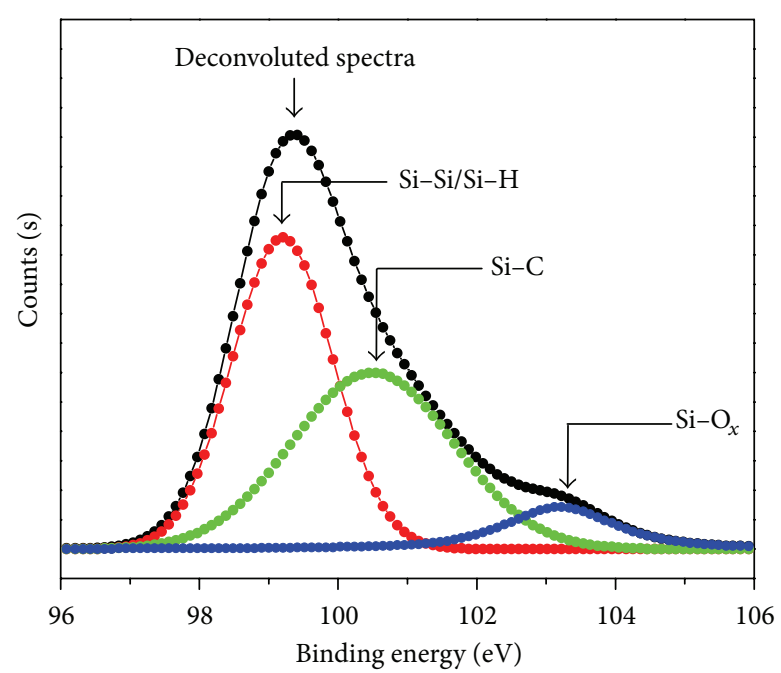

(b) $\mathrm{Si} 2 \mathrm{p}$

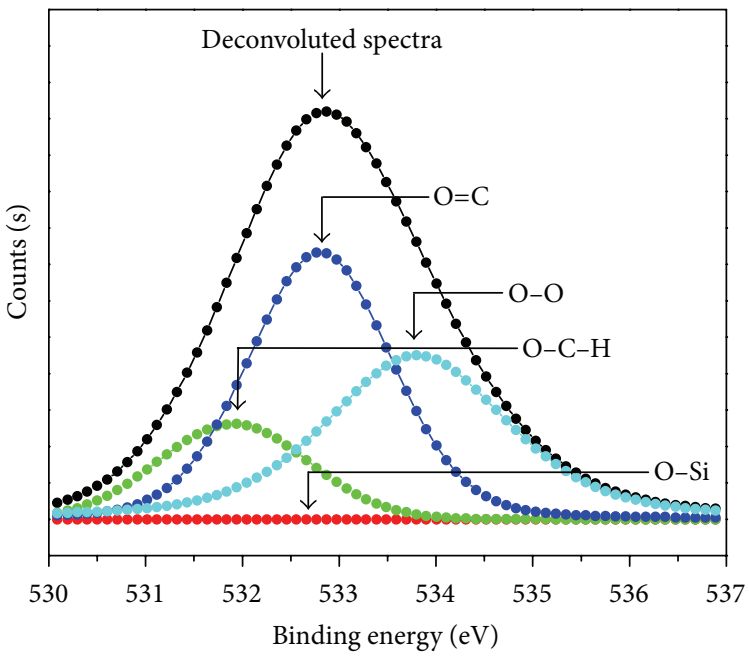

(d) $\mathrm{O} 1 \mathrm{~s}$

FIGURE 7: Typical XPS spectra for SiC:H film deposited at 350 mTorr by HW-CVD method: (a) wide scan, (b) deconvoluted XPS spectra of $\mathrm{Si}(2 \mathrm{p})$ in the range $96 \mathrm{eV}-106 \mathrm{eV}$, (c) deconvoluted XPS spectra of C (1s) in the range $280 \mathrm{eV}-292 \mathrm{eV}$, and (d) deconvoluted XPS spectra of O (1s) in the range $530 \mathrm{eV}-537 \mathrm{eV}$.

has been estimated and found to be $46 \%, 41 \%$, and $8.3 \%$, for silicon, carbon, and oxygen, respectively. However, it is interesting to note that we have successfully grown the $\mathrm{SiC}: \mathrm{H}$ films using HW-CVD from methane as carbon source gas. This is important from technology point of view.

3.6. UV-Visible Spectroscopy Analysis. The optical properties of the HW-CVD grown SiC:H films at various deposition pressures were investigated from UV-visible spectroscopy. The nature of transition involved (direct or indirect) during the optical absorption process can be determined by studying the dependence of absorption coefficient on the incident photon energy using the Tauc equation [58]:

$$
\alpha=\frac{A\left(h \nu-E_{g}\right)^{\gamma}}{h \nu},
$$

TABLE 2: Energy peak positions obtained in XPS analysis of SiC:H films prepared by HW-CVD [48-57].

\begin{tabular}{lc}
\hline $\begin{array}{l}\text { Bonding } \\
\text { configuration }\end{array}$ & $\begin{array}{c}\text { Energy peak position } \\
\text { (binding energy) }(\mathrm{eV})\end{array}$ \\
\hline $\mathrm{Si}-\mathrm{O}_{x}$ & 103.2 \\
$\mathrm{C}-\mathrm{Si}$ & 283.2 \\
$\mathrm{C}-\mathrm{C}$ & 284.6 \\
$\mathrm{C}-\mathrm{O}-\mathrm{H}$ & 286.4 \\
$\mathrm{C}=\mathrm{O}$ & 288.4 \\
$\mathrm{O}-\mathrm{Si}$ & 531.2 \\
$\mathrm{O}-\mathrm{C}-\mathrm{H}$ & 531.9 \\
$\mathrm{O}=\mathrm{C}$ & 532.8 \\
$\mathrm{O}-\mathrm{O}$ & 533.8 \\
\hline
\end{tabular}




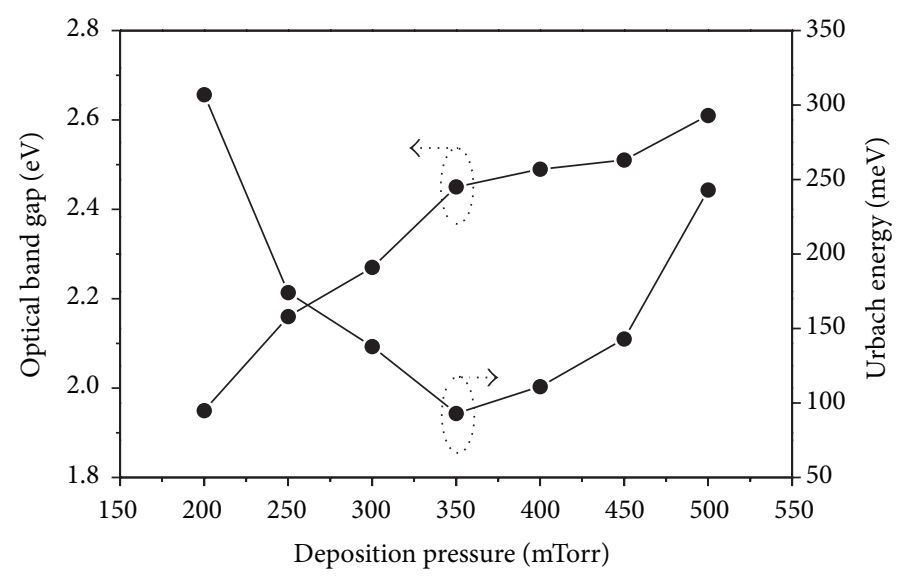

FIGURE 8: Variation in band gap and Urbach energy as a function of deposition pressure.

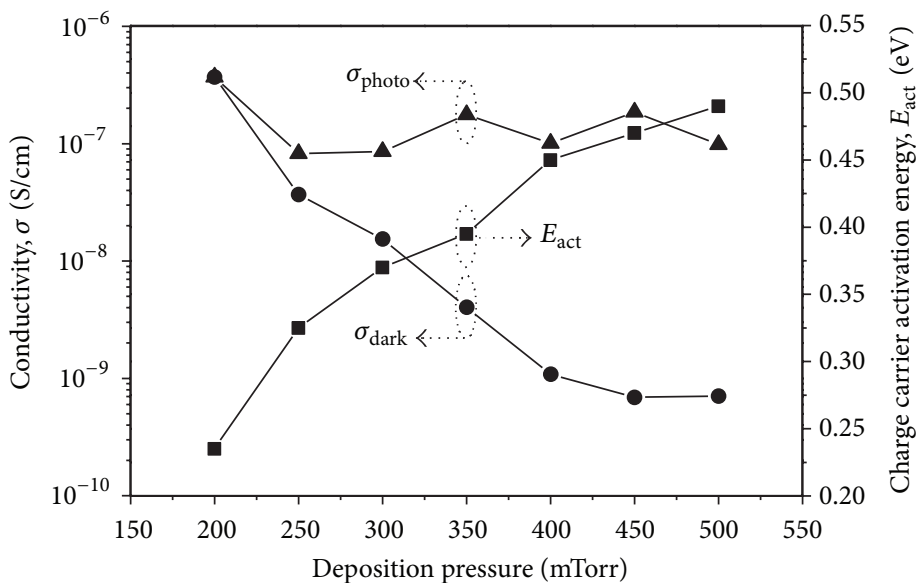

FIGURE 9: Variation of dark conductivity and its charge carrier activation energy and photoconductivity as a function of deposition pressure of $\mathrm{SiC}: \mathrm{H}$ films deposited by the HW-CVD method.

where $h \nu$ is the photon energy and $A$ and $\gamma$ are constants. The exponent $\gamma$ depends upon the type of transition and has value of 2 and $1 / 2$ for indirect and direct transition, respectively.

It is well known that $\mathrm{SiC}: \mathrm{H}$ is the direct gap semiconductor, so $\gamma=2$ can be used to determine the band gaps of $\mathrm{SiC}: \mathrm{H}$ films. The Urbach energy was extracted from exponential tail region in which the absorption coefficient $(\alpha)$ follows the exponential decay with photon energy $(h v)$ as

$$
\alpha=\alpha_{o} \exp \left(\frac{h v}{E_{U}}\right)
$$

where $\alpha_{o}$ is a constant and $E_{U}$ is the Urbach energy that characterizes the exponential slope of the energy dependence. Figure 8 shows the dependence of band gap and Urbach energy on deposition pressure $\left(P_{d}\right)$.

As seen from the figure, the band gap increases from $1.95 \mathrm{eV}$ to $2.61 \mathrm{eV}$ when deposition pressure varied from 200 mTorr to 500 mTorr. The main factors that affect the band gap of $\mathrm{SiC}: \mathrm{H}$ films are the $\mathrm{C}$ to $\mathrm{Si}$ ratio, the amount of hydrogen, and crystalline fraction [59]. Increase in band gap may be due to increase in total hydrogen and carbon content in the film with increase in deposition pressure. The FTIR spectroscopy further supports this. Our FTIR spectroscopy analysis shows increase in hydrogen and carbon content in the films with increase in deposition pressure (see Figures 3(a) and 3(d)). As a result, the band gap increases with increase in deposition pressure. The Urbach energy decreases from $307 \mathrm{meV}$ to $93 \mathrm{meV}$ when deposition pressure increased from 200 mTorr to 350 mTorr. Further, increase in deposition pressure upto 500 mTorr, the Urbach energy again increase. These values are much higher than the Urbach energy values obtained for device quality a-Si $i_{1-x} \mathrm{C}_{x}$ films deposited by PECVD [60] and ECR-PE-CVD [61]. The high value of Urbach energy suggests increased structural disorder in HW-CVD grown $\mathrm{SiC}: \mathrm{H}$ films resulting from alloying of $\mathrm{Si}$ with $\mathrm{C}$.

3.7. Electrical Properties. Figure 9 demonstrates the variation of dark conductivity $\left(\sigma_{\text {dark }}\right)$ and its charge carrier activation energy $\left(E_{\text {act }}\right)$ and photoconductivity $\left(\sigma_{\text {Photo }}\right)$ as a function of the deposition pressure.

It can be seen from the figure that the dark conductivity decreases from $3.6 \times 10^{-7} \mathrm{~S} / \mathrm{cm}$ to $7.1 \times 10^{-10} \mathrm{~S} / \mathrm{cm}$ when deposition pressure increases from 200 mTorr to 500 mTorr. 
The charge carrier activation energy values show a reverse trend. It increases from $0.24 \mathrm{eV}$ to $0.5 \mathrm{eV}$ as deposition pressure increases from 200 mTorr to 500 mTorr. However, the photoconductivity remains almost constant at $\sim 10^{-7} \mathrm{~S} / \mathrm{cm}$ over the entire range of deposition pressure studied. As a result, the photosensitivity, taken as the ratio of photoconductivity to dark conductivity $\left(\sigma_{\text {Photo }} / \sigma_{\text {dark }}\right)$, increases from 1 to $10^{3}$ when deposition pressure increases from 200 mTorr to 500 mTorr. We attribute that enhancement in photosensitivity gain is due to amorphization in $\mathrm{SiC}: \mathrm{H}$ films with increasing deposition pressure. The $\mu \mathrm{c}-\mathrm{Si}: \mathrm{H} / \mathrm{nc}-\mathrm{Si}: \mathrm{H}$ films prepared by different methods show high dark conductivity and negligible photosensitivity gain depending upon the crystallite size and its volume fraction [62]. The X-ray diffraction (Figure 5) and Raman spectroscopy analysis (Figure 6) support this conjecture. This inference is further strengthened by the observed variation in deposition rate with deposition pressure (Figure 1) since lower deposition rate is more favorable to the formation of crystallites in the film structure [63].

\section{Conclusions}

In this work, $\mathrm{SiC}: \mathrm{H}$ films have been fabricated by $\mathrm{HW}$ CVD using the mixture of $\mathrm{SiH}_{4}$ and $\mathrm{CH}_{4}$ at low substrate temperature $\left(250^{\circ} \mathrm{C}\right)$ at reasonably high deposition rates $\left(9.4 \mathrm{~nm} / \mathrm{s}<r_{d}<15.54 \mathrm{~nm} / \mathrm{s}\right)$. The structural, optical, and electrical properties of the deposited films are investigated by XRD, XPS, FTIR, Raman, and UV-Visible spectroscopy as a function of deposition pressure. The deposition pressure was varied from 200 mTorr to 500 mTorr. Formation of SiC:H films has been confirmed by FTIR, Raman, and XPS analysis. The XRD and Raman analysis revealed that with increase in deposition pressure amorphization takes place in $\mathrm{SiC}: \mathrm{H}$ films. The FTIR spectroscopy analysis shows decrease in $\mathrm{C}-\mathrm{H}$ bond density while $\mathrm{Si}-\mathrm{C}$ and $\mathrm{Si}-\mathrm{H}$ bond densities increase with increase in deposition pressure. The absence of band at $\sim 1300-1600 \mathrm{~cm}^{-1}$ in the Raman spectra implies negligible $\mathrm{C}-\mathrm{C}$ bond concentration and formation of nearly stoichiometric $\mathrm{SiC}: \mathrm{H}$ films. The band gap shows increasing trend with increase in deposition pressure. The high value of Urbach energy suggests increased structural disorder in HW-CVD grown SiC:H films resulting from alloying of $\mathrm{Si}$ with $\mathrm{C}$. Finally, it has been concluded that $\mathrm{CH}_{4}$ can be used as effective carbon source in HW-CVD method to prepare stoichiometric SiC:H films.

\section{Conflict of Interests}

All the authors hereby declare that there is no conflict of interests regarding the publication of above mentioned paper.

\section{Acknowledgments}

This work was financially supported by Department of Science and Technology (DST) and Ministry of New and Renewable Energy (MNRE), Government of India and Center for Nanomaterials and Quantum Systems (CNQS), University of Pune. The author V. S. Waman is thankful to Bank of Maharashtra, University of Pune branch, for the financial support.

\section{References}

[1] L. S. Chang, P. L. Gender, and J. H. Jou, "Thermal, mechanical and chemical effects in the degradation of the plasma-deposited $\alpha$-SiC:H passivation layer in a multilayer thin-film device," Journal of Materials Science, vol. 26, no. 7, pp. 1882-1890, 1991.

[2] Y. Matsumoto, G. Hirata, H. Takakura, H. Okamoto, and Y. Hamakawa, "A new type of high efficiency with a low-cost solar cell having the structure of a $\mu \mathrm{c}-\mathrm{SiC} /$ polycrystalline silicon heterojunction," Journal of Applied Physics, vol. 67, no. 10, pp. 6538-6543, 1990.

[3] U. Coscia, G. Ambrosone, C. Minarini et al., "Laser annealing of hydrogenated amorphous silicon-carbon films," Thin Solid Films, vol. 453-454, pp. 7-12, 2004.

[4] H. Windischmann, "Intrinsic stress and mechanical properties of hydrogenated silicon carbide produced by plasma-enhanced chemical vapor deposition," Journal of Vacuum Science and Technology A, vol. 9, no. 4, pp. 2459-2463, 1991.

[5] S. X. Li, Y. Q. Cao, J. Xu, Y. J. Rui, W. Li, and K. J. Chen, "Hydrogenated amorphous silicon-carbide thin films with high photo-sensitivity prepared by layer-by-layer hydrogen annealing technique," Applied Surface Science, vol. 270, pp. 287-291, 2013.

[6] C. Ricciardi, G. Fanchini, and P. Mandracci, "Physical properties of ECR-CVD polycrystalline $\mathrm{SiC}$ films for micro-electromechanical systems," Diamond and Related Materials, vol. 12, no. 3-7, pp. 1236-1240, 2003.

[7] S. M. Rajab, I. C. Oliveira, M. Massi, H. S. Maciel, S. G. dos Santos Filho, and R. D. Mansano, "Effect of the thermal annealing on the electrical and physical properties of $\mathrm{SiC}$ thin films produced by RF magnetron sputtering," Thin Solid Films, vol. 515, no. 1, pp. 170-175, 2006.

[8] G. Soto, E. C. Samano, R. Machorro, and L. Cota, "Growth of $\mathrm{SiC}$ and $\mathrm{SiC}_{x} \mathrm{~N}_{y}$ films by pulsed laser ablation of $\mathrm{SiC}$ in $\mathrm{Ar}$ and $\mathrm{N}_{2}$ environments," Journal of Vacuum Science and Technology A, vol. 16, no. 3, pp. 1311-1315, 1998.

[9] Q. Wang, S. Y. Fu, S. L. Qu, and W. J. Liu, "Enhanced photoluminescence from $\mathrm{Si}^{+}$and $\mathrm{C}^{+}$ions co-implanted porous silicon formed by electrochemical anodization," Solid State Communications, vol. 144, no. 7-8, pp. 277-281, 2007.

[10] H. Ishihara, M. Murano, T. Watahiki, A. Yamada, M. Konagai, and Y. Nakamura, "Growth of strain relaxed $\mathrm{Si}_{1-y} \mathrm{C}_{y}$ on Si buffer layer by gas-source MBE," Thin Solid Films, vol. 508, no. 1-2, pp. 99-102, 2006.

[11] P. Mandracci, Growth and characterization of SiC thin films by a plasma assisted technique for electronic applications [Ph.D. thesis], Trento University, Trento, Italy, 2001.

[12] Y. Avigal, M. Schieber, and R. Levin, "The growth of heteroepitaxial SiC films by pyrolysis of various alkyl-silicon compounds," Journal of Crystal Growth, vol. 24-25, pp. 188-192, 1974.

[13] K. Takahashi, S. Nishino, J. Saraie, and K. Harada, in SPP Amorphous and Crystalline Silicon Carbide IV, C. Y. Yang, M. M. Rahaman, and G. L. Harris, Eds., pp. 71-78, Springer, Berlin, Germany, 1992.

[14] C. Jacob, P. Pirouz, and S. Nishino, "Low temperature selective and lateral epitaxial growth of silicon carbide on patterned silicon substrates," Materials Science Forum, vol. 353-356, pp. 127-130, 2001.

[15] C. Ricciardi, A. Primiceli, G. Germani, A. Rusconi, and F. Giorgis, "Microstructure analysis of a-SiC: $\mathrm{H}$ thin films grown by high-growth-rate PECVD," Journal of Non-Crystalline Solids, vol. 352, no. 9-20, pp. 1380-1383, 2006. 
[16] A. Tabata, Y. Komura, T. Narita, and A. Kondo, "Growth of silicon carbide thin films by hot-wire chemical vapor deposition from $\mathrm{SiH}_{4} / \mathrm{CH}_{4} / \mathrm{H}_{2}$," Thin Solid Films, vol. 517, no. 12, pp. 35163519, 2009.

[17] S. Klein, R. Carius, F. Finger, and L. Houben, "Low substrate temperature deposition of crystalline $\mathrm{SiC}$ using HWCVD," Thin Solid Films, vol. 501, no. 1-2, pp. 169-172, 2006.

[18] T. Chen, Y. Huang, A. Dasgupta et al., "Microcrystalline silicon carbide window layers in thin film silicon solar cells," Solar Energy Materials and Solar Cells, vol. 98, pp. 370-378, 2012.

[19] M. R. Badaruddin, M. R. Muhamad, and S. A. Rahman, "Multiphase structured silicon carbon nitride thin films prepared by hot-wire chemical vapour deposition," Thin Solid Films, vol. 519, no. 15, pp. 5082-5085, 2011.

[20] T. Chen, F. Köhler, A. Heidt, Y. Huang, F. Finger, and R. Carius, "Microstructure and electronic properties of microcrystalline silicon carbide thin films prepared by hot-wire CVD," Thin Solid Films, vol. 519, no. 14, pp. 4511-4515, 2011.

[21] T. Wu, H. Shen, B. Cheng, Y. Pan, B. Liu, and J. Shen, "Formation of $\alpha-\mathrm{Si}_{1-x} \mathrm{C}_{x}: \mathrm{H}$ and nc-SiC films grown by HWCVD under different process pressure," Applied Surface Science, vol. 258, no. 3, pp. 999-1003, 2011.

[22] F. S. Tehrani, B. T. Goh, M. R. Muhamad, and S. A. Rahman, "Pressure dependent structural and optical properties of silicon carbide thin films deposited by hot wire chemical vapor deposition from pure silane and methane gases," Journal of Materials Science, vol. 24, no. 4, pp. 1361-1368, 2013.

[23] A. Tabata and Y. Komura, "Preparation of nanocrystalline cubic silicon carbide thin films by hot-wire CVD at various filamentto-substrate distances," Surface and Coatings Technology, vol. 201, no. 22-23, pp. 8986-8990, 2007.

[24] V. S. Waman, M. M. Kamble, M. R. Pramod et al., "Nanostructured hydrogenated silicon films by hot-wire chemical vapor deposition: the influence of substrate temperature on material properties," Journal of Nano and Electronic Physics, vol. 3, p. 590, 2011.

[25] R. Swanepoel, "Determination of the thickness and optical constants of amorphous silicon," Journal of Physics E, vol. 16, no. 12, p. $1214,1983$.

[26] S. Kasap and P. Capper, Springer Handbook of Electronic and Photonic Materials, Springer, New York, NY, USA, 2006.

[27] M. Mori, A. Tabata, and T. Mizutani, "Properties of hydrogenated amorphous silicon carbide films prepared at various hydrogen gas flow rates by hot-wire chemical vapor deposition," Thin Solid Films, vol. 501, no. 1-2, pp. 177-180, 2006.

[28] Q. Cheng, J. Long, Z. Ni, A. Rider, and K. Ostrikov, "High-rate, low-temperature synthesis of composition controlled hydrogenated amorphous silicon carbide films in low-frequency inductively coupled plasmas," Journal of Physics D, vol. 41, no. 5, Article ID 055406, 2008.

[29] J. Karimi, A. B. A. Dow, and N. P. Kherani, "Stoichiometric amorphous hydrogenated silicon carbide thin film synthesis using DC-saddle plasma enhanced chemical vapour deposition," in Proceedings of the IEEE 5th International Nanoelectronics Conference (INEC '13), pp. 160-163, Singapore, January 2013.

[30] G. Lucovsky, R. J. Nemanich, and J. C. Knights, "Structural interpretation of the vibrational spectra of a-Si: H alloys," Physical Review B, vol. 19, no. 4, pp. 2064-2073, 1979.

[31] Y. H. Wang, J. Lin, and C. H. A. Huan, "Multiphase structure of hydrogenated amorphous silicon carbide thin films," Materials Science and Engineering B, vol. 95, no. 1, pp. 43-50, 2002.
[32] A. Tabata, M. Kuroda, M. Mori, T. Mizutani, and Y. Suzuoki, "Band gap control of hydrogenated amorphous silicon carbide films prepared by hot-wire chemical vapor deposition," Journal of Non-Crystalline Solids, vol. 338-340, no. 1, pp. 521-524, 2004.

[33] G. Ambrosone, P. Capezzuto, S. Catalanotti, U. Coscia, and S. Mormone, "Optical, electrical and structural properties of hydrogenated amorphous Si-C alloys deposited by different hydrocarbon gas mixtures," Philosophical Magazine B, vol. 80, no. 4, pp. 497-506, 2000.

[34] M. Kuenle, S. Janz, O. Eibl, C. Berthold, V. Presser, and K.-G. Nickel, "Thermal annealing of $\mathrm{SiC}$ thin films with varying stoichiometry," Materials Science and Engineering B, vol. 159-160, pp. 355-360, 2009.

[35] T. Kaneko, D. Nemoto, A. Horiguchi, and N. Miyakawa, "FTIR analysis of a-SiC:H films grown by plasma enhanced CVD," Journal of Crystal Growth, vol. 275, no. 1-2, pp. e1097-e1101, 2005.

[36] M. T. Kim and J. Lee, "Characterization of amorphous SiC:H films deposited from hexamethyldisilazane," Thin Solid Films, vol. 303, no. 1-2, pp. 173-179, 1997.

[37] M. M. Brodsky, M. Catdona, and J. J. Canmo, "Infrared and Raman spectra of the silicon-hydrogen bonds in amorphous silicon prepared by glow discharge and sputtering," Physical Review B, vol. 16, no. 8, pp. 3556-3571, 1977.

[38] S. Ray, D. Das, and A. K. Barua, "Infrared vibrational spectra of hydrogenated amorphous silicon carbide thin films prepared by glow discharge," Solar Energy Materials, vol. 15, no. 1, pp. 45-57, 1987.

[39] K. Basa and F. W. Smith, "Infrared study of amorphous crystalline phase transition in an annealed amorphous hydrogenated silicon carbon alloy film," Materials Research Society Proceedings, vol. 162, p. 439, 1990.

[40] H. Shanks, C. J. Fang, L. Ley, M. Cardona, F. J. Desmond, and S. Kalbitzer, "Infrared spectrum and structure of hydrogenated amorphous silicon," Physica Status Solidi B, vol. 100, no. 1, pp. 43-56, 1980.

[41] F. S. Tehrani, M. R. Badaruddin, R. G. Rahbari, M. R. Muhamad, and S. A. Rahman, "Low-pressure synthesis and characterization of multiphase $\mathrm{SiC}$ by HWCVD using $\mathrm{CH}_{4} / \mathrm{SiH}_{4}$," Vacuum, vol. 86, no. 8, pp. 1150-1154, 2012.

[42] B. P. Swain and R. O. Dusane, "Multiphase structure of hydrogen diluted a-SiC:H deposited by HWCVD," Materials Chemistry and Physics, vol. 99, no. 2-3, pp. 240-246, 2006.

[43] G. Y. Xu, T. M. Wang, G. H. Li, Z. X. Ma, and G. Z. Zheng, "Raman spectra of nanocrystalline silicon films," Chinese Journal of Semiconductors, vol. 21, pp. 1170-176, 2000.

[44] S. Nakashima and H. Harima, "Raman investigation of $\mathrm{SiC}$ polytypes," Physica Status Solidi A, vol. 162, no. 1, pp. 39-64, 1997.

[45] T. Tanaka, E. Maruyama, T. Shimida, and H. Okamoto, Amorphous Silicon, John Wiley and Sons, Chichester, UK, 1999.

[46] K. Chew, R. Rusli, S. F. Yoon et al., "Hydrogenated amorphous silicon carbide deposition using electron cyclotron resonance chemical vapor deposition under high microwave power and strong hydrogen dilution," Journal of Applied Physics, vol. 92, no. 5, p. 2937, 2002.

[47] K. Karch, P. Pavone, W. Windl, O. Schütt, and D. Strauch, "Ab initio calculation of structural and lattice-dynamical properties of silicon carbide," Physical Review B, vol. 50, no. 23, pp. 1705417063, 1994.

[48] M. A. El Khakani, M. Chaker, A. Jean et al., "Effect of rapid thermal annealing on both the stress and the bonding states of a-SiC:H films," Journal of Applied Physics, vol. 74, no. 4, pp. 2834-2840, 1993. 
[49] I. Soloman, M. P. Schmidt, C. Sénémaud, and K. M. Driss, "Band structure of carbonated amorphous silicon studied by optical, photoelectron, and x-ray spectroscopy," Physical Review B, vol. 38, pp. 13263-13270, 1988.

[50] I. Solomon, M. P. Schmidt, and H. Tran-Quoc, "Selective lowpower plasma decomposition of silane-methane mixtures for the preparation of methylated amorphous silicon," Physical Review B, vol. 38, no. 14, pp. 9895-9901, 1988.

[51] S. E. Hicks, A. G. Fitzgerald, S. H. Baker, and T. J. Dines, "The structural, chemical and compositional nature of amorphous silicon carbide films," Philosophical Magazine B, vol. 62, no. 2, pp. 193-212, 1990.

[52] W. Y. Lee, "X-ray photoelectron spectroscopy and Auger electron spectroscopy studies of glow discharge $\mathrm{Si}_{1-x} \mathrm{C}_{x}: \mathrm{H}$ films," Journal of Applied Physics, vol. 51, no. 6, p. 3365, 1980.

[53] L. Smith and K. M. J. Black, "Characterization of the treated surfaces of silicon alloyed pyrolytic carbon and SiC," Journal of Vacuum Science and Technology A, vol. 2, no. 2, p. 744, 1984.

[54] W. K. Choi, F. L. Loo, C. H. Ling, F. C. Loh, and K. L. Tan, "Structural and electrical studies of radio frequency sputtered hydrogenated amorphous silicon carbide films," Journal of Applied Physics, vol. 78, no. 12, pp. 7289-7294, 1995.

[55] E. Gat, M. A. E. Khakani, M. Chaker et al., "Study of the effect of composition on the microstructural evolution of a- $\mathrm{Si}_{x} \mathrm{C}_{1-x}: \mathrm{H}$ PECVD films. IR absorption and XPS characterizations," Journal of Materials Research, vol. 7, no. 9, pp. 2478-2487, 1992.

[56] R. C. Lee, C. R. Aita, and N. C. Tran, "The air-exposed surface of sputter deposited silicon carbide studied by x-ray photoelectron spectroscopy," Journal of Vacuum Science and Technology A, vol. 9, no. 3, p. 1351, 1991.

[57] M. Katiyar, Y. H. Yang, and J. R. Abelson, "Si-C-H bonding in amorphous $\mathrm{Si}_{1-x} \mathrm{C}_{x}: \mathrm{H}$ film/substrate interfaces determined by real time infrared absorption during reactive magnetron sputter deposition," Journal of Applied Physics, vol. 78, no. 3, p. 1659, 1995.

[58] J. Tauc, Amorphous and Liquid Semiconductors, Plenum Publication, London, UK, 1974.

[59] T. Rajagopalan, X. Wang, B. Lahlouh, C. Ramkumar, P. Dutta, and S. Gangopadhyay, "Low temperature deposition of nanocrystalline silicon carbide films by plasma enhanced chemical vapor deposition and their structural and optical characterization," Journal of Applied Physics, vol. 94, no. 8, pp. 5252-5260, 2003.

[60] S. H. Baker, W. E. Spear, and R. A. G. Gibson, "Electronic and optical properties of a- $\mathrm{Si}_{1-x} \mathrm{C}_{x}$ films prepared from a $\mathrm{H}_{2}$-diluted mixture of $\mathrm{SiH}_{4}$ and $\mathrm{CH}_{4}$," Philosophical Magazine B, vol. 62, no. 2, pp. 213-223, 1990.

[61] J. P. Conde, V. Chu, M. F. da Silva et al., "Optoelectronic and structural properties of amorphous silicon-carbon alloys deposited by low-power electron-cyclotron resonance plasmaenhanced chemical-vapor deposition," Journal of Applied Physics, vol. 85, no. 6, pp. 3327-3338, 1999.

[62] T. Saitoh, T. Shimada, M. Migitaka, and Y. Tarui, "Preparation and properties of microcrystalline silicon films using photochemical vapor deposition," Journal of Non-Crystalline Solids, vol. 59-60, no. 2, pp. 715-718, 1983.

[63] S. C. Saha, A. K. Barua, and S. Ray, "The role of hydrogen dilution and radio frequency power in the formation of microcrystallinity of n-type Si:H thin film," Journal of Applied Physics, vol. 74, no. 9, pp. 5561-5568, 1993. 

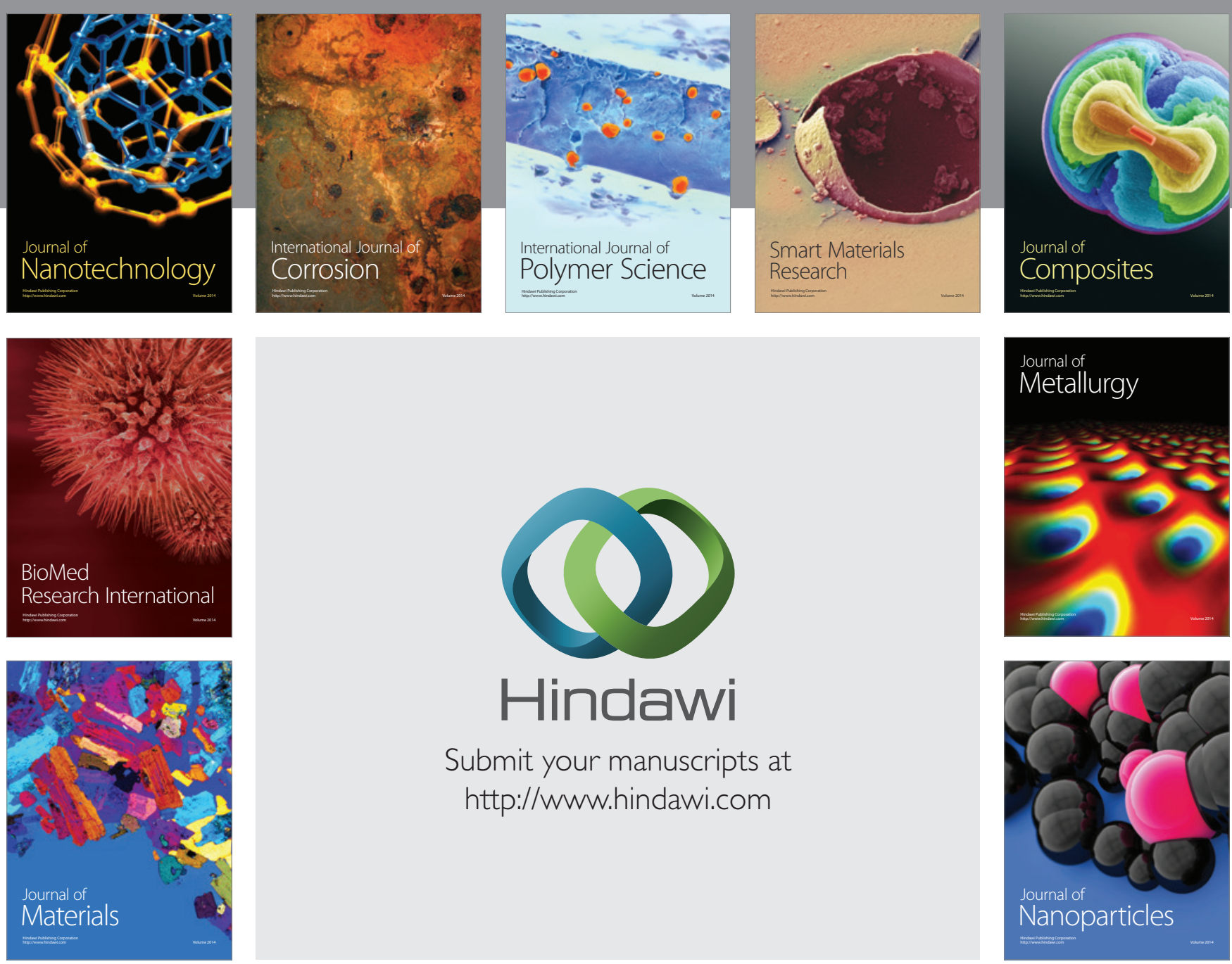

Submit your manuscripts at http://www.hindawi.com
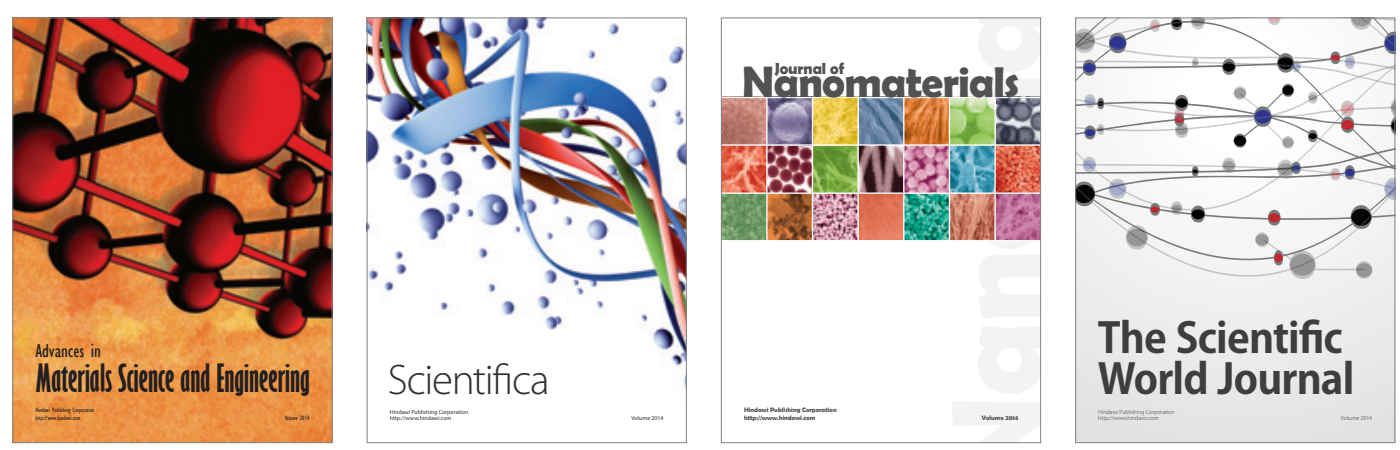

\section{The Scientific World Journal}
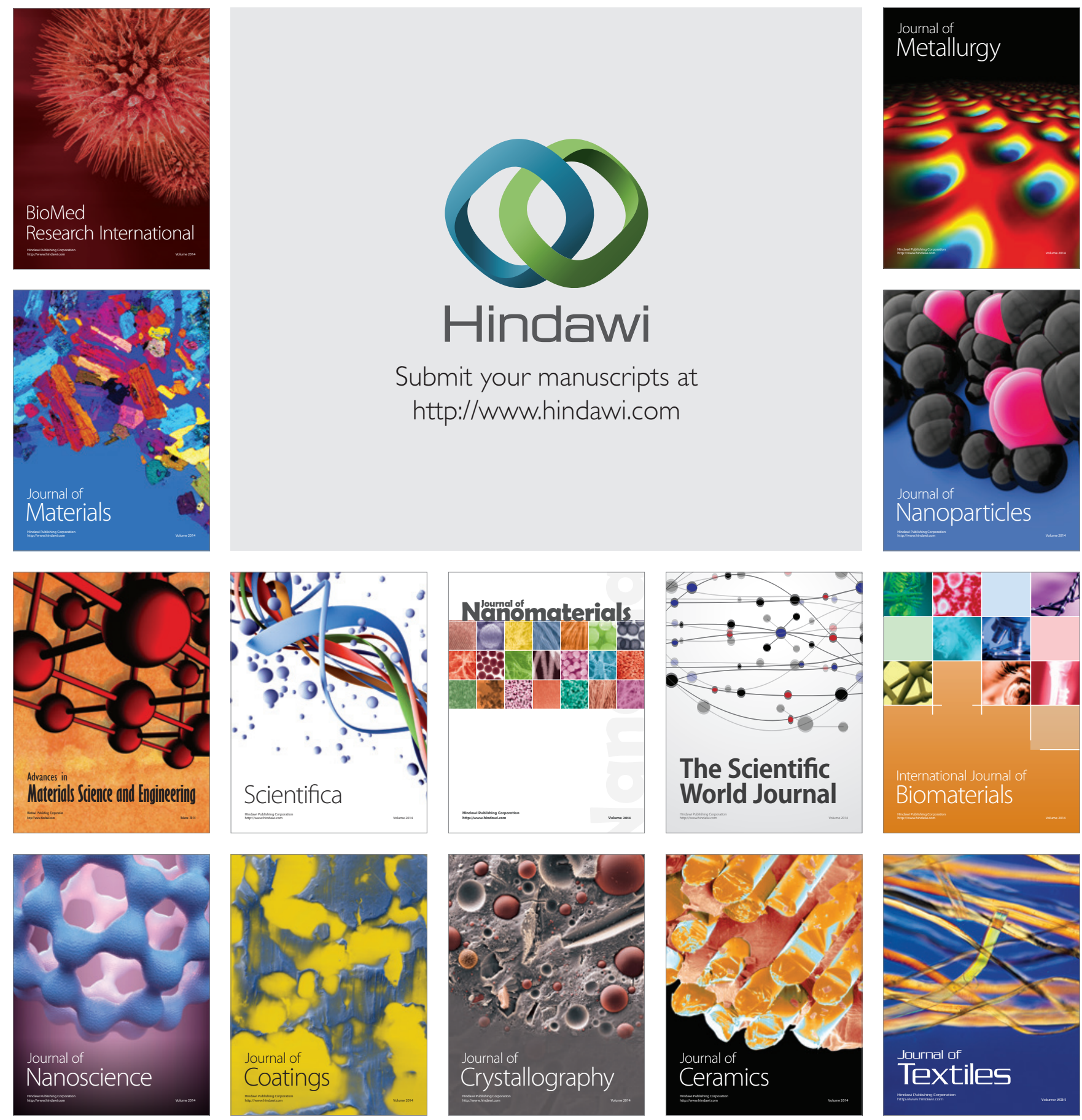